\title{
ANALISIS KINERJA KEUANGAN DENGAN MENGGUNAKAN METODE ECONOMIC VALUE ADDED (EVA) PADA PT. INDO FOOD SUKSES MAKMUR.TBK
}

\author{
Rudy Chairudin ${ }^{1}$, Kartawinata ${ }^{2}$ \\ 1,2, Dosen jurusan Manajemen, Universitas Tridinanti, Sumatera Selatan \\ 1)Email : rudychair62@gmail.com
}

\begin{abstract}
INFORMASI ARTIKEL
ABSTRAK

Tujuan penelitian ini untuk mengetahui kinerja keuangan perusahaan serta sebagai bahan informasi bagi masyarakat dalam berinvestasi pada suatu

Submitted:

$06 / 01 / 2021$

Revised:

$25 / 05 / 2021$

Accepted:

$27 / 06 / 2021$

Online-Published:

$30 / 06 / 2021$ perusahaan. Sebagai salah satu pengukuran kinerja keuangan adalah Economic Value Added (EVA) dimana alat ini digunakan untuk mengukur hasil kinerja keuangan perusahaan serta untuk mengetahui apakah hasil keputusan manajemen atau keuangan perusahaan selama ini dapat meningkat atau menurun. keuangan perusahaan. Dari hasil penelitian ini dapat disimpulkan bahwa PT. Indo Food Sukkses Makmur Indonesia memiliki kinerja keuangan yang memuaskan terutama pada tahun 2017 dan 2019 yang memiliki nilai EVA positif, sedangkan untuk tahun 2018 memiliki nilai EVA negatif karena adanya kenaikan harga pokok penjualan dan biaya keuangan dalam penggunaan utang jangka pendek.
\end{abstract}

Kata Kunci: eva, kinerja keuangan

\begin{abstract}
ABSTRACK
The purpose of this study is find out the company's financial performance as well as information material for the public in investing in a company. As one of the measurements of financial performance is Economic Value Added (EVA) where this tool is used to measure the results of the company's financial performance as well as to find out whether the results of management or corporate financial decisions so far can increase or decrease the company's finances. From the results of this study it can be concluded that PT. Indo Food Sukkses Makmur Indonesia has a satisfactory financial performance, especially in 2017 and 2019 which has a positive EVA value, while for 2018 it has a negative EVA value due to an increase in cost of goods sold and financial costs in the use of short-term debt
\end{abstract}

Keywords : eva, financial performance

\section{A. PENDAHULUAN}

Semakin banyaknya bermunculan suatu perusahaan maka akan membuat persaingan semakin ketat di dalam dunia bisnis. Manajemen perusahaan di wajibkan harus mampu bersaing dan menunjukkan kemampuan kinerja yang baik dan luas agar dapat membuat para investor tertarik untuk menanamkan modalnya kepada perusahaan. Dari persaingan yang cukup ketat ini pula akan membawa dampak pengaruh yang sangat kuat pada kinerja perusahaan. PT Indofood Sukses Makmur Tbk. merupakan salah satu perusahaan yang dipandang cukup berhasil di Indonesia dalam memproduksi berbagai macam barang konsumsi terkenal, disamping itu PT Indofood juga termasuk ke dalam pasar modal syariah. Melihat hal ini di pandang perlu untuk menganalisa kinerjanya
Banyak pilihan yang bisa digunakan bagi perusahaan untuk menilai peningkatan prestasi keuangan perusahaan, salah satunya adalah dengan cara menghitung Economic Value Added, dimana dari hasil penghitungan ini dapat mengetahui kinerja keuangan perusahaan apakah kinerja perusahaan mengalami perkembangan atau penurunan, hal ini tidak terlepas dari keputusan keputusan yang telah diambil oleh pengambil keputusan keuangan perusahaan didalam pengelolaaannya.. Berdasarkan latar belakang diatas, maka judul yang digunakan dalam penulisan ilmiah ini adalah "Analisis Kinerja Keuangan dengan Menggunakan Metode Economic Value Added (EVA) Pada PT. Indo Food Sukkses Makmur. 
Berdasarkan uraian diatas, maka perumusan masalahnya adalah :

1. Bagaimana kinerja perusahaan pada PT. Indo Food Sukses Makmurt Tbk, apabila diukur dengan menggunakan metode Economic Value Added (EVA)

2. Apakah perusahaan memiliki Nilai Tambah Ekonomis?

Sedangkan, berdasarkan latar belakang yang diuraikan diatas, penelitian hanya menghitung kinerja keuangan PT. Indo Food Sukkses Makmur dengan menggunakan metode EVA untuk mengetahui apakah kinerja perusahaan tersebut baik atau tidak sehingga bisa mempengaruhi pengambilan keputusan calon penanam modal dengan periode pengamatan tahun 2017 sampai 2019.

Adapun tujuan dari penilitian ini adalah sebagai berikut:

1. Untuk mengetahui kinerja perusahaan dengan menggunakan metode EVA. Dari hasil dari perhitungan dengan menggunakan Economic Value Added dapat digunakan sebagai bahan pertimbangan bagi calon penanam modal untuk pengambilan keputusan dalam menanamkan modalnya.

2. Untuk mengetahui apakah perusahaan memiliki nilai tambah ekonomis atau tidak

Adapun manfaat yang diharapkan dari hasil penelitian ini adalah sebagai berikut

1. Bagi penulis

Dengan adanya penelitian ini diharapkan dapat memberikan tambahan informasi serta dapat memperluas cakrawala berpikir bagi penulis, sehingga dapat memajukan ilmu pengetahuan tentang dunia keuangan. Sebagai bahan pertimbangan dalam melakukan perbaikan atau peningkatan kinerja keuangan perusahaan serta menerapkan alat ukur kinerja keuangan perusahaan yang dapat mencerminkan pertumbuhan perusahaan dengan tepat.

2. Bagi Investor

\begin{abstract}
Membantu investor dalam mengetahui kondisi, potensi dan perkembangan perusahaan untuk kemudian dapat mengambil suatu keputusan investasi.
\end{abstract}

\section{B. METODE PENELITIAN Objek Penelitian}

Objek penelitian yang dilakukan oleh penulis adalah PT. Indo Food Sukkses Makmur . Dalam penelitian ini sumber data yang digunakan adalah sumber data sekunder yang diperoleh melalui media internet untuk menerangkan kinerja perusahaan dengan menggunakan penilaian tambah ekonomis atau EVA (Economic Value Added)

\section{Data Variabel}

Pengumpulan data penelitian ini kemudian disajikan secara Statistic Inferensi untuk mengetahui hasil kinerja keuangan PT. Indo Food Sukses Makmur Indonesia dengan pendekatan kuantatif yang berdasarkan pada data sekunder yang diperoleh dari media internet berupa laporan PT. Indo Food Sukkses Makmur.

\section{Metode Pengumpulan Data}

Data yang digunakan adalah data yang didapat dari media internet berupa Annual Report Tahunan PT. Indo Food Sukkses Makmur.

\section{HASIL DAN PEMBAHASAN}

\section{Lapotan Neraca PT.Indo Food Sukses} Makmur Tbk sbb :

Tabel 1. Perhitungan Neraca PT. Indo Food Sukses Makmur, Tbk Periode 20172019 (disajikan dalam Miliar Rupiah) 
Jurnal Kompetitif, Vol. 10, No. 1, hal. 85 - 91, Edisi Januari 2021

p-ISSN 2302-4585; e-ISSN 2721-3765

\begin{tabular}{|l|l|l|l|}
\hline & \multicolumn{1}{|c|}{$\mathbf{2 0 1 9}$} & \multicolumn{1}{c|}{$\mathbf{2 0 1 8}$} & \multicolumn{1}{c|}{$\mathbf{2 0 1 7}$} \\
\hline Aktiva Lancar & $32.704,970$ & $35.553,231$ & $32.201,072$ \\
\hline Aktiva Tidak Lancar & $64.356,662$ & $60.435,976$ & $56.037,923$ \\
\hline $\begin{array}{l}\text { Liabilitas Jangka } \\
\text { Pendek }\end{array}$ & $27.474,862$ & $31.45,755$ & $21.937,652$ \\
\hline $\begin{array}{l}\text { Liabilitas Jangka } \\
\text { Panjang }\end{array}$ & $17.620,019$ & $15.999,68$ & $20.342,082$ \\
\hline Total Equitas & $51.966,751$ & $48.553,764$ & $45.964,261$ \\
\hline
\end{tabular}

Tabel 2. Laporan Perhitungan R/L Perusahaan PT. Indo Food Sukses Makmur .TBK.

Tahun 2017-2019

\begin{tabular}{|c|c|c|c|}
\hline & $\mathbf{2 0 1 9}$ & $\mathbf{2 0 1 8}$ & $\mathbf{2 0 1 7}$ \\
\hline Penjualan & 57.845 .448 & 54.742 .187 & 53.120 .225 \\
\hline $\begin{array}{c}\text { Beban Pokok } \\
\text { Penjualan }\end{array}$ & 40.846 .528 & 39.272 .319 & 37.820 .131 \\
\hline Laba Bruto & 16.998 .920 & 15.469 .868 & 15.300 .094 \\
\hline $\begin{array}{c}\text { Beban } \\
\text { Umum,Penjualan, } \\
\text { distribusi dan } \\
\text { Administrasi, dan } \\
\text { (Beban operasi lain) }\end{array}$ & 9.497 .456 & 8.340 .536 & 8.083 .411 \\
\hline EBIT & 7.501 .464 & & \\
\hline Beban keuangan & 1.306 .065 & 1.833 .323 & 1.092 .033 \\
\hline EBT & 6.195 .399 & 5.296 .009 & 6.124 .648 \\
\hline Beban Pajak & 2.000 .001 & 1.715 .919 & 1.809 .248 \\
\hline $\begin{array}{c}\text { Laba Periode } \\
\text { Berjalan }\end{array}$ & $\mathbf{4 . 1 9 5 . 3 9 8}$ & $\mathbf{3 . 5 8 0 . 0 9 0}$ & $\mathbf{4 . 1 3 5 . 4 0 0}$ \\
\hline $\begin{array}{c}\text { Bagian Penghasilan } \\
\text { Komprehensif dan } \\
\text { entitas lain }\end{array}$ & $\mathbf{2 3 6 . 3 9 7}$ & $\mathbf{7 4 3 . 2 2 0}$ & $\mathbf{3 8 2 . 3 4 5}$ \\
\hline $\begin{array}{c}\text { Total Laba } \\
\text { Komprehensif } \\
\text { Periode Berjalan }\end{array}$ & $\mathbf{4 . 4 3 1 . 7 9 5}$ & $\mathbf{4 . 3 2 3 . 3 1 0}$ & $\mathbf{4 . 5 1 7 . 7 4 5}$ \\
\hline EPS & & & 373 \\
\hline
\end{tabular}

Dari Tabel Diatas dapat dilihat bahwa Total Laba comprehensf perusahaan dari tahun 2017 ke 2018 mengalami penurunan sebesar $4 \%$. Walaupun adanya peningkatan penjualan sebesar $3.05 \%$ akan tetapi laju pertambahan Beban Pokok Penjualan $3.83 \%$ yang lebih besar. Selanjutnya laba perusahaan mengalami peningkatan kembali dari tahun 2018 ke 2019 sebesar 2, $50 \%$ sedangkan beban pokoknya hanya mengalami peningkatan sebesar $4 \%$ dan terjadinya peningkatan penjualan sebesar 5,7\%.

2. Perhitungan NOPAT dengan rumus EBIT $(!-t)$ maka didapatkan hasilnya sebagai berikut :
Tabel 3. PT. Indo Food Sukses Makmur . TBK Tahun 2017-2019

\begin{tabular}{|c|c|c|c|}
\hline & $\mathbf{2 0 1 9}$ & $\mathbf{2 0 1 8}$ & $\mathbf{2 0 1 7}$ \\
\hline EBIT & 7.501 .464 & 7.129 .332 & 7.216 .683 \\
\hline Tax & 0.3228 & 0.3240 & 0.2954 \\
\hline NOPAT & 5.079 .991 & 4.819 .428 & 5.084 .875 \\
\hline \multicolumn{4}{|c|}{ Dari tabel diatas tanpak EBIT }
\end{tabular}

perusahaan untuk tahun 2018 mengalami penurunan sebesar 1,2 persen. Hal ini terjadi karena walaupun adanya peningkatan penjualan tetapi pertambahan harga pokok perusahaan laju pertambahannya lebih besar. Untuk tahun 2018 ke 2019 EBIT perusahaan mengalami peningkatan kembali sebesar $5.278 \%$ akibat dari peningkatan penjualan yang lebih besar walaupun adanya 
Jurnal Kompetitif, Vol. 10, No. 1, hal. 85 - 91, Edisi Januari 2021 p-ISSN 2302-4585; e-ISSN 2721-3765

peningkatan harga pokok penjualan perusahaan.

\section{Untuk Perhitungan Invested Capital Sebagai berikut :}

Tabel 4. Perhitungan Invested Capital PT. Indo Food Sukses Makmur . TBK Tahun 2017-2019

\begin{tabular}{|c|c|c|c|}
\hline \multicolumn{2019}{|c|}{$\mathbf{2 0 1 8}$} & $\mathbf{2 0 1 7}$ \\
\hline $\begin{array}{c}\text { Total } \\
\text { Hutang }\end{array}$ & 45.094 .881 & 47.435 .443 & 42.279 .734 \\
\hline Equitas & 51.966 .751 & 48.553 .764 & 45.964 .261 \\
\hline $\begin{array}{c}\text { Hutang } \\
\text { Jangka } \\
\text { Pendek }\end{array}$ & 27.474 .862 & 31.435 .755 & 21.937 .652 \\
\hline $\begin{array}{c}\text { Invested } \\
\text { Capital }\end{array}$ & 69.546 .770 & 64.553 .452 & 66.306 .343 \\
\hline
\end{tabular}

Dari tabel diatas tanpak Total hutang perusahaan tahun 2017 ke 2018 Mengalami peningkatan sebesar $12,19 \%$ dan equitas maupun hutang jangka pendek juga mengalami peningkatan masing-masing sebesar $5.6 \%$ dan 43,29\%. Sehingga invested capital mengalami penurunan sebesar $2.64 \%$. Untuk Tahun 2018 ke 2019 Total Hutang mengalami penurunan sebesar $4.9 \%$, dan equitas mengalami kenaikan sebesar 7,02 \% Sedangkan Hutang jangka pendeknya mengalami penurunan sebesar $12,59 \%$ sehingga mengakibatkan menaiknya invested capital sebesar 7,7\%.
4. erhitungan Debt toAssets Ratio sbb :

Tabel 5 Menghitung Debt to Assets Ratio PT.Indo Food Sukses Makmur 2017-2019

\begin{tabular}{|c|c|c|c|}
\hline & $\mathbf{2 0 1 9}$ & $\mathbf{2 0 1 8}$ & $\mathbf{2 0 1 7}$ \\
\hline Total & 45.094 .881 & 47.435 .443 & 42.279 .734 \\
Hutang & & & \\
\hline Total & 97.061 .632 & 95.989 .207 & 88.238 .995 \\
Aktiva & & & \\
\hline Debt to & $0.4646 /$ & $0.4941 /$ & $0.4791 /$ \\
Assets & $46.460 \%$ & $49.417 \%$ & $47.915 \%$ \\
Ratio(D) & & & \\
\hline
\end{tabular}

Dari tabel diatas tanpak Total Hutang perusahaan tahun 2017 ke 2018 Mengalami peningkatan sebesar $12,19 \%$ dan Total Aktiva meningkat sebesar $8,78 \%$. Sehingga Debt to Assets ratio mengalami peningkatan sebesar $3.13 \%$. Untuk tahun 20182019 Total Hutang mengalami penurunan sebesar $4,9 \%$ sedangkan total aktiva meningkat sebesar $1,117 \%$ sehingga mengakibatkan Debt to assets ratio mengalami penurunan sebesar $5,98 \%$

\section{Perhitungan Cost of debt PT.Indo Food Sukses Makmur .Tbk Tahun 2017 dan 2018 Sbb :}

Tabel 6. Menghitung Cost Of Debt Indo Food Sukses Makmur . TBK Tahun 2017-2019

\begin{tabular}{|c|c|c|c|}
\hline & $\mathbf{2 0 1 9}$ & $\mathbf{2 0 1 8}$ & $\mathbf{2 0 1 7}$ \\
\hline Beban & 1.306 .065 & 1.833 .323 & 1.092 .033 \\
Bunga & & & \\
\hline $\begin{array}{c}\text { Total } \\
\text { liabilitas }\end{array}$ & 17.620 .019 & 15.999 .688 & 20.342 .082 \\
$\begin{array}{c}\text { Jangka } \\
\text { Panjang }\end{array}$ & & & \\
\hline $\begin{array}{c}\text { Cost Of } \\
\text { Debt } \\
\text { (rd) }\end{array}$ & $0.07412 / 7.412 \%$ & $0.11459 / 11.459 \%$ & $0.05368 / 5.368 \%$ \\
\hline
\end{tabular}

Pada tabel diatas untuk beban bunga Perusahaan Indo Fod Sukses makmur Tbk tahun 2017 ke 2018 mengalami Peningkatan sebesar $67,88 \%$ Sedangkan total liablitas jangka panjang turun sebesar 21,34\% sehingga mengakibatkan cost of debt mengalami peningkatan sebesar $113 \%$. Hal ini diakibatkan oleh hutang jangka pendek yang meningkat dengan tingkat bunga yang lebih besar walaupun secara total jumlah hutang menurun . Untuk Tahun 2018 ke 2019 beban bunga mengalami penurunan sebesar $28.76 \%$ sedangkan total laibilitas jangka panjang hanya naik sebesar $10,12 \%$, 
sehingga Cost ob debt mengalami penurunan sebesar $35.32 \%$.

6. Menghitung Tingkat Modal

Tabel 7. Tingkat Modal PT.Indo Food Sukses Makmur 2017-2019

\begin{tabular}{|c|c|c|c|}
\hline & $\mathbf{2 0 1 9}$ & $\mathbf{2 0 1 8}$ & $\mathbf{2 0 1 7}$ \\
\hline Equitas & 51.966 .751 & 48.553 .764 & 45.964 .261 \\
\hline $\begin{array}{c}\text { Total Hutang dan } \\
\text { Equitas }\end{array}$ & 97.061 .632 & 95.989 .207 & 88.243 .995 \\
\hline Tingkat Modal (E) & $0.53539 / 53.539 \%$ & $0.50582 / 50.582 \%$ & $0.52087 / 52.087 \%$ \\
\hline & $\begin{array}{l}\text { mengalami kenaikan sebesar 7,03 \% } \\
\text { sedangkan total hutang dan equitas } \\
\text { mengalami peningkatan sebesar 1,11\% } \\
\text { Equitas Perusahaan PT Indo Food }\end{array}$ & $\begin{array}{l}\text { sehingga mengakibatkan tingkat modal } \\
\text { Sukses Makmur Tbk untuk tahun 2017 ke }\end{array}$
\end{tabular}

2018 mengalami kenaikan sebesar $5.63 \%$ sedangkan total hutang dan equitas naik sebesar $8.77 \%$ sehingga tingkat modal mengalami penurunan sebesar $2.89 \%$. Untuk tahun 2018 ke 2019 tingkat equitas mengalami kenaikan sebesar $5,85 \%$

Tabel 8. Rentabilitas Modal PT.Indo FoodSukses Makmur. Tbk.Tahun 2017-2019

\begin{tabular}{|c|c|c|c|}
\hline & 2019 & 2018 & 2017 \\
\hline EAT & 4.431 .795 & 4.323 .310 & 4.517 .745 \\
\hline Equity & 51.966 .751 & 48.553 .764 & 45.964 .261 \\
\hline Re & $0.08528 / 8.528 \%$ & $0.08904 / 8.904 \%$ & $0.09828 / 9.828 \%$ \\
\hline
\end{tabular}

Pada tahun 2017 ke 2018 untuk EAT perusahaan turun sebesar $4,3 \%$ sedangkan tingkat equity naik sebesar $5,63 \%$. ini mengakibatkan Rentabilitas moda sendiri (re) mengalami penurunan sebesar $9,40 \%$. Untuk tahun 2018 ke 2019 EAT perusahaan Tabel 9. Beban Pajak PT.Indo FoodSukses Makmur. Tbk Tahun 2017-2019

\begin{tabular}{|c|c|c|c|}
\hline & $\mathbf{2 0 1 9}$ & $\mathbf{2 0 1 8}$ & $\mathbf{2 0 1 7}$ \\
\hline Beban Pajak & 2.000 .001 & 1.715 .919 & 1.809 .248 \\
\hline $\begin{array}{c}\text { Laba Bersih selum } \\
\text { Pajak }\end{array}$ & 6.195 .399 & 5.296 .009 & 6.124 .648 \\
\hline Tax & $0.3228 / 32.28 \%$ & $0.3240 / 32.40 \%$ & $0.2954 / 29.54 \%$ \\
\hline
\end{tabular}

Untuk Beban Pajak Pada PT.Indo food sukses makmur tahun 2017 ke 2018 mengalami penurunan sebsar 7.12 persen dan kemudian tahun 2019 mengalami kenaikan kembali sebesar $10.54 \%$. Dari tabel diatas juga tanpak bahwa besaran laba bersih sebelum pajak PT.Indo Fod Sukses Makmur TBK untuk tahun 2017 ke 2018 amengalami penurunan sebesar $29,54 \%$ lalu mengalami

\begin{tabular}{|c|c|c|c|}
\hline & $\mathbf{2 0 1 9}$ & $\mathbf{2 0 1 8}$ & $\mathbf{2 0 1 7}$ \\
\hline \begin{tabular}{c} 
WACC $=\begin{array}{c}\{(\mathrm{D} \mathrm{X} \text { rd })(1-\mathrm{t})+(\mathrm{E} \\
\text { xre })\}\end{array}$ \\
\hline
\end{tabular} & 0,06895 & 0.0839 & 0,0693 \\
\hline
\end{tabular}


10. Menghitung Capital Charges sbb:

11. Tabel 11. Capital Charge PT.Indo FoodSukses Makmur. Tbk Tahun 2017-2019

\begin{tabular}{|c|c|c|c|}
\hline & $\mathbf{2 0 1 9}$ & $\mathbf{2 0 1 8}$ & $\mathbf{2 0 1 7}$ \\
\hline $\begin{array}{c}\text { Invested } \\
\text { Capital }\end{array}$ & 69.546 .770 & 64.553 .452 & 66.306 .343 \\
\hline WACC & 0,06895 & 0.0839 & 0,0693 \\
\hline $\begin{array}{c}\text { Capital } \\
\text { Charges }\end{array}$ & 4.795 .249 & 5.416 .034 & 4.595 .029 \\
\hline
\end{tabular}

Dari tabel diatas Capital charge perusahaan untuk tahun 2017 ke 2018 mengalami kenaikan sebesar $17,86 \%$ hal ini akibat dari invested capital perusahaan mengalami penurunan $2,64 \%$. Untuk tahun 2018 ke 2019 capital charge mengalami penurunan sebesar $11.46 \%$ akibat dari invested capital perusahaan yang mengalami kenaikan sebesar 7 i .73\%. Hal ini terjadi Walaupun invested capital mengalami kenaikan akan tetapi invested capital dilakukan dengan menggunakan hutang jangka panjang sehingga wacc (weighted average cost of capital )perusahaan mengalami penurunan sebesar $17.8 \%$.

\section{Menghitung Economic Value Added sbb:}

Tabel 12. EVA PT.Indo FoodSukses Makmur. Tbk Tahun 2017-2019

\begin{tabular}{|c|c|c|c|}
\hline & $\mathbf{2 0 1 9}$ & $\mathbf{2 0 1 8}$ & $\mathbf{2 0 1 7}$ \\
\hline NOPAT & 5.079 .991 & 4.819 .428 & 5.084 .875 \\
\hline $\begin{array}{c}\text { Capital } \\
\text { Charges }\end{array}$ & 4.795 .249 & 5.416 .034 & 4.595 .029 \\
\hline EVA & 284.742 & $0<$ & 489.846 \\
\hline
\end{tabular}

Economic Value Added perusahaan dari tabel diatas tanpak 2017 mengalami positip, kemudian tahun 2018 mengalami negatip akibat dari realisasi modal perusahaan yang menggunakan hutang jangka pendek dimana beban keuangan perusahaan untuk jangka pendek secara relatif pertanggungannya menjadi lebih besar dibanding dengan menggunakan hutang jangka panjang. Disamping itu beban harga pokok penjualan adalah $71.74 \%$ lebih besar dari tahun 2017 dan 2019 yang masing -masing $71.19 \%$ dan $70.61 \%$. Hal ini akibat dari perusahaan indofood adalah perusahaan dalam makanan dan minuman yang kebutuhannya banyak mengkonsumsi tepung terigu dimana menurut ketua umum asosiasi pengusaha tepung terigu Indonesa (Aptindo) Fransiscus Welirang kebutuhan akan import gandum sedang mengalami pertumbuhan sebesar $5 \%$ dari realisasi impor pada tahun lalu sebanyak 10.09 juta ton, padahal harga gandum dunia pada saat itu sedang meningkat. Kemudian untuk tahun 2019 EVA mengalami positip kembali. Karena adanya peningkatan penjualan perusahaan walaupun diikuti peningkatan harga pokoknya akan tetapi laju pertambahan peningkatan penjualan pertambahannya masih lebih besar. secara keseluruhan PT Indo food Sukses Makmur Tbk EVA nya masih tetap lebih besar dari 0 (nol) untuk hun 2017 dan 2019 hal ini menunjukkan banwa kinerja perusahaan sudah cukup memuaskan untuk kinerjanya.

\section{SIMPULAN DAN SARAN \\ 1. Simpulan}

1. Nilai Eva perusahaan untuk masing masing tahun 2017 dan 2019 masih mengalami positip dengan Nilai NOPAT lebih lebih besar daripada capital Chargenya atau lebih besar daripada 0 (nol) kecuali untuk tahun 2018 yang nilai Eva nya lebih kecil dari 0 (nol)

2. Kineja keuangan perusahaan untuk tahun 2017-2019 sudah cukup memuaskan maka perlu dapat menjadi perhatian bagi ivestor untuk berinvestasi dipasar modal

\section{E. DAFTAR RUJUKAN}

Albertus, Indratno. 2013. Prinsip-Prinsip Dasar Akuntansi. Jakarta.

Darsono \& Ashari. 2005. Pedoman Praktis Memahami Laporan Keuangan. Yogyakarta : ANDI.

Harahap, Sofyan. Syafri. 2013. Analisis Kritik atas Laporan Keuangan. Jakarta : Pustaka Quantum.

Harahap, Sofyan. Syafri. 2001. Akuntansi Islam menuju perumusan teori. Jakarta : Pustaka Quantum.

James O. Gill \& Moira Chatton. 2003. Memahami Laporan Keuangan. Jakarta. 
Jurnal Kompetitif, Vol. 10, No. 1, hal. 85 - 91, Edisi Januari 2021

p-ISSN 2302-4585; e-ISSN 2721-3765

Resmi, Siti. 2002. Jurnal Akuntansi dan Manajemen. Yogyakarta : STIE YKPN.

Tunggal, Amin. Widjaja. 2001. Memahami Economic Value Added (EVA) Teori dan Kasus. Jakarta : Harvindo.

Tunggal, Amin. Widjaja. 2008. Pengantar Konsep Economic Value Added (EVA )dan Value Based Management (VBM). Jakarta : Harvindo. 